\title{
The Effect of Periwinkle Shell Ash (PSA) Blended With Cement on the Compressive and Abrasive Properties of Lateritic Block
}

\author{
Antia Mfon Ekanem, Ajiero Ikenna Reginald, Ulaeto Nsikak William ${ }^{1}$
}

\begin{abstract}
The study seeks to investigate the effect of Periwinkle Shell Ash (PSA) blended with cement on the compressive and abrasive properties of lateritic block. In order to determine the suitability of materials for block making, tests like sedimentation test, standard proctor test, Atterberg's limit test, smell and Nibble tests were carried out on the laterite. Also specific gravity of PSA, bulk density and porosity of PSA were carried out. $5 \%$ of the binder and percentage replacement levels of $0 \%, 10 \%, 20 \%, 30 \%, 40 \%$ and $50 \%$ of cement with PSA were used for block production. $210 \mathrm{~mm}$ X $100 \mathrm{~mm}$ X $100 \mathrm{~mm}$ blocks were cast; cured and subjected to compressive strength and abrasive strength test. Data were collected, presented and analysed using graphs, correlation and regression methods of analysis. Result shows that the compressive strength values obtained from $0 \%$ to $30 \%$ replacement at the 28th day were high $\left(4.52 \mathrm{~N} / \mathrm{mm}^{2}, 4.02 \mathrm{~N} / \mathrm{mm}^{2}, 3.49 \mathrm{~N} / \mathrm{mm}^{2}\right.$ and $2.56 \mathrm{~N} / \mathrm{mm}^{2}$ for $0 \%, 10 \%, 20 \%$ and $30 \%$ replacement respectively). A gradual increase in strength of the blocks was also observed as the curing age increased. At $10 \%$ replacement for instance the compressive strength at $7^{\text {th }}, 14^{\text {th }}$ and $28^{\text {th }}$ days were $14 \mathrm{~N} / \mathrm{mm}^{2}$, $2.81 \mathrm{~N} / \mathrm{mm}^{2}$ and $4.02 \mathrm{~N} / \mathrm{mm}^{2}$. The abrasive coefficient of the lateritic block was calculated as a percentage of the sandcrete block of mix 1:6. The abrasive coefficient reduces as the percentage replacement increases. For instance, at $0 \%$ replacement it was 73 , reduces to 64 at $10 \%, 59$ at $20 \%$ and 51 at $30 \%$ replacement of cement with PSA. Beyond $30 \%$ the abrasive coefficient was below recommended values.
\end{abstract}

Index Terms - Lateritic blocks, periwinkle shell ash, pozzolana.

\section{INTRODUCTION}

\section{A. Background of the study}

One of the most striking features of the demographic shift-taking place in the world is the drastic growth in world population. In Nigeria for instance, the National Population Census Commission reports that, the population of Nigeria by 1953 was 30.42 million, by 1963 the population was 55.6 million and currently, the population estimate is over 140 million. This shows a progressive increase in population with a resultant increase in the demand for houses. This phenomenon is common among the developing countries. In such countries, homelessness and the incidence of people living in poor housing and unhealthy neighbourhoods are rapidly increasing. The housing problem is acute especially in the urban areas due to the shortage of affordable housing

Antia, Mfon Ekanem, Department of Building, University of Uyo, Uyo, Nigeria

Ajiero, Ikenna Reginald, Department of Building, University of Uyo, Uyo, Nigeria

Ulaeto, Nsikak William, Department of Building, University of Uyo, Uyo, Nigeria for the low - income earners and the poor who constitute over $70 \%$ of the urban population (Mustapha, 2004). This has resulted in proliferation of slums and squatter settlements. It was estimated that by 2020 Nigeria will require between 12.5 and 14 million dwelling units of various types (Mustapha, 2004). He also stated that, Nigeria must build at the rate of 1.2 million houses a year to meet the current demand. Government concerted efforts at providing affordable shelter for the citizens are greatly undermined by the continuous rise in population. Added to this is the prohibitive cost of creating building structures. The constantly increasing cost of construction is often attributed to the high cost of materials (Arilesere, 2005).

In advanced countries, the cost of materials is relatively low while in the under developed or developing countries like Nigeria - materials cost is very high (Udegbe, 2005). The situation is worsened by the fact that Nigeria according to Lilly and Wai (2002) is import dependent. They maintained that Nigeria imports more than $70 \%$ of the total quantity of the cement used within the country. This excessive importation has mounted a serious pressure on the economy of the nation, thereby making housing development for the Nigerian populace a difficult task to come by.

In view of the situation so stated, it becomes imperative to source for and produce building materials within the country that will be affordable and durable but at the same time meeting the standards specified in building codes. The engineering properties mostly required in block production are high compressive strength, durability and abrasion resistance among others. To improve these properties researchers have used various additives/techniques for the production of soil blocks with a view of bringing down the high cost of building. For instance, a report by Okpoko and Ali (2005) reveals that compaction of soil blocks reduces porosity, increases density as well as increasing the compressive strength, resistance to water absorption and wind abrasion. Meukam, et al (2002) opined that a cement additive of about $8 \%$ is adequate to give the desired reduction in water absorption. They went further to state that beyond $8 \%$, the supplementary addition of cement has no effect on the water absorption. Adesanya (2000) maintained that when cement and corncob are used to produce soil blocks the compressive strength is increased greatly, but corncob on the other hand tends to increase water absorption.

This research envisages that incorporating periwinkle shell ash in cement will produce lateritic blocks that will combine high compressive and abrasive strength. If this is achieved, then a new era of cheap affordable and durable accommodation for the Nigerian populace is underway. 


\section{B. Statement of problem}

Despite the constant outcry of successive governments in Nigeria towards solving accommodation problem for its citizens, the problem of affordable and durable accommodation for citizens of the country remains a mirage or rather an illusion and unachievable dream. The erstwhile United Nation declaration of housing for all by the year 2000 to which Nigeria was a signatory, culminated into the National Housing Scheme. The scheme is yet to make a measurable impact in solving the accommodation problem. Various reasons can be adduced to this problem, like high cost of building materials, which is paralleled by low per capita income. Materials used in the country are either imported or manufactured with high technology in large scale industries. The high demand for foreign exchange, capital intensive nature and huge over - head cost in the manufacturing and procurement of these materials consequently translate into high cost of finished building materials.

However, literature is replete with reports on the use of local, affordable and cheap materials to produce lateritic blocks with measurable levels of successes and failures. Hence, there is need to source for materials that will effectively replace these weaknesses. If this is achieved, it will launch the global community into a new horizon and enhance the affordability of durable houses by the citizens of the country.

\section{Aim and objectives of the study}

The aim of the study is to examine the engineering properties of lateritic blocks produced by partially replacing cement with periwinkle shell ash, with a view to providing information on the suitability of the block as walling material. The objectives that would help to achieve the stated aim are to

i. Examine the effect of periwinkle shell ash/cement on the compressive strength of lateritic blocks.

ii. Examine the abrasive strength of lateritic blocks blended with cement and periwinkle shell ash.

\section{LITERATURE REVIEW}

\section{A. Soil Block Stabilization}

Stabilization as defined by Adam and Agib (2001) is the process of adding stabilizers (such as lime, cement, bitumen, Gypsum, pozzolanas and organic fibre) to the soil block to improve its strength and durability. Stabilization can also be achieved by compaction of the soil block (Okpoko and Ali, 2005). There are several methods of soil stabilization widely used to improve construction quality, which include mechanical stabilization, physical stabilization and chemical stabilization.

Mechanical stabilization as defined by Craig (2004) is the process of increasing the density of soil by packing the particles closer together with a reduction in the volume of air. Afrin (2017) sees it as the introduction of pressure on the soil which results in changes of the properties of the soil like its density, permeability and compressive strength. $\mathrm{He}$ maintained that the degree of compaction possible is affected greatly by the type of soil used, the moisture content during compaction and the compressive effort applied. Best result can be obtained by mixing the correct proportions of sand and clay in a soil. More recent developments for roads and embankment construction have led to compacting soil with vibrating rollers and tampers. Tampers and block-making presses are also used for single storied constructions. The major drawback of mechanically compressed stabilized earth block as reported by (Guillaud and Joffroy (1999) is their lack of durability especially in places of moderate to high rainfall. Manual stabilization or compaction methods vary from foot trading to hand ramping (Adam and Agib, 2001). The strength of soil is determined by the type of soil and sizes of grain particles that makeup the soil. In physical stabilization attempts is made to alter the composition of the soil particles. Okpoko and Ali (2005) maintained that to have a well-graded soil from predominantly clay soil, appropriate proportions of other soil types like sand and silt can be added to such soil to improve its quality.

\section{B. Compressive Strength of Soil Block}

Compressive strength may be defined as the failure load of a material per unit area. It determines how many loads a material can carry. It is a measure of the local bearing capacity of a material. The sandcrete block - with suitable mix of 1: 8 - normally used in construction has over the years proved to be suitable in areas free of chemicals attack such as sulphate and aluminate, such blocks have higher compressive strength quite above the limit of $2.75 \mathrm{~N} / \mathrm{mm}$; adequate for both bungalows and high rise buildings as specified in BS 3921 (1974).

Okpoko and Ali (2005) opined that when stabilizing agents such as fibre, cement, lime, bitumen and earthworm cast are added to the soil, the strength of the soil is improved. They went on to assert that compaction of the soil also increases the density and compressive strength as well as reducing the permeability and porosity of the soil. By implication, Okpoko and Ali are saying that fillers can be used to stabilize the soil block in order to lower its cost without unduly lowering the materials characteristics below acceptable limit. Balami and lzam (1998) reported that soils stabilized with bitumen tip to $2.5 \%$ produced blocks with optimal compressive strength of $1.7 \mathrm{~N} / \mathrm{mm}^{2}$. Although the compressive strength is high and commendable, availability and cost implication far outstrips that of cement since bitumen has an alternative use in road construction. A report by Okoli (1998) shows that soils stabilized with lime having $9 \%$ lime, $40 \%$ clay and $51 \%$ laterite by weight have a maximum compressive strength of $5.33 \mathrm{~N} / \mathrm{mm}^{2}$ and exhibit the highest water resistance capacity.

Adesanya (2000) reported a high compressive strength of $5.5 \mathrm{~N} / \mathrm{mm}^{2}$ at 28 days for cement, laterite and corncob ash mix. Waziri et al (2013) reported that compressive strength is highest with cement stabilized soil block than soil blocks stabilized with OPC/RHA. They went further to state that in the $40 \%$ and $50 \%$ RHA in 6\% cement and $40 \%, 50 \%$ and $60 \%$ RHA in $8 \%$ cement, the compressive strength values met the minimum requirement of $1.4 \mathrm{~N} / \mathrm{mm}^{2}$ for the construction of bungalows. Similarly, $40 \%$ RHA in $10 \%$, $40 \%, 50 \%$ and $60 \%$ in $12 \%$ cement, the compressive strength was above $2.75 \mathrm{~N} / \mathrm{mm}^{2}$ stipulated by building regulation for the construction of load bearing walls up to 2-storied building. They further recommended that for optimum utilization, mix containing 50\% RHA in $8 \%$ and $12 \%$ cement 
should be used in bungalows and load bearing walls respectively. Though the compressive strength values obtained by some researchers fall below the recommended value of $2.8 \mathrm{~N} / \mathrm{mm}^{2}$ for storied buildings, they are all suitable for low-rise buildings with a recommended value of $1.4 \mathrm{~N} / \mathrm{mm}^{2}$ (BS 3921, 1974).

\section{Abrasive strength of soil blocks}

Abrasive strength is the mass of lost matter per mass of block before abrasion. Abrasive strength is closely linked to the nature of soil and the rate of stabilization. It is not directly linked to mechanical strength. That is, the mechanical strength may be high when the abrasive strength of the same material is low. The resistance of the lateritic block to abrasion determines its durability. The abrasive strength of sandcrete blocks has over the years been commendable; hence, sandcrete block is known to be durable and is used widely for construction. Eko et al. (2006) revealed that earth block had been in use before $70 \mathrm{~s}$, but that it poorly resists erosion. They argued that the abrasive strength of earth block was low, but persistence in research has helped to reveal some techniques and additives that improved the abrasive strength of the earth block. For instance, Craig (2004), Okpoko and Ali (2005) maintained that compaction of soil increases the resistance of soil block to abrasive wind, Here, they are of the opinion that soil compaction increases the abrasive resistance of soil blocks.

Eko et al. (2006) opined that stabilization of compressed earth block using cement increase the abrasive strength of the block. They also stated that compressed earth block should be fully stabilized for it to be effective as partial stabilization decreases its abrasive strength. They also stated that beyond a certain level of stabilization with cement, the soil block would no longer be economical. This is in consonance with the $8 \%$ by weight optimum for stabilizer (cement) quoted by Houben and Guillaud (1995) and Rigassi (1995).

\section{Methodology}

\section{A. Specimens preparation}

A total of 55 blocks were cast out of which 45 was used to test for compressive strength and 10 blocks were used to test for abrasive strength. The materials were batched by volume with various proportions of its components. The proportions used were; $5 \%$ cement; $0 \%, 10 \%, 20 \%, 30 \%, 40 \%$ and $50 \%$ periwinkle shell ash (PSA) to replace the cement.

The soil was sieved using a 4.75 sieve size to obtain a homogenous soil. Cement was replaced by $0 \%, 10 \%, 20 \%$, $30 \% 40 \%$ and $50 \%$ of PSA by volume. In each case $5 \%$ of the resulting binder by volume was thoroughly mixed with laterite. The optimum moisture content of $10 \%$ by weight of the laterite soil was added. Water was sprinkled on the mixture using watering can. The mixing was continued until a homogeneous mix was obtained. The resulting paste was compacted in a $210 \mathrm{~mm} \times 100 \mathrm{~mm} \times 100 \mathrm{~mm}$ mould.

\section{B. Testing of Soil Blocks}

The suitability of the block for wall construction was determined through tests such as compressive strength and abrasive tests.

\section{1) Compressive Strength Test}

This test was carried out as guided in American Standard for Testing of materials (1978). The compressive strength of the lateritic block was tested at the 7th, 14th and 28th days. To determine the strength, the specimen ends were sanded smooth, and then placed on the bottom bearing plate of the testing machine. The steel top bearing plate was set on top of the specimen, which ensured a uniform pressure over the upper cross-section of the specimen. The top and bottom plates were identical. The specimen was loaded. The load kept increasing as indicated by the meter. At a point were failure occurred, no further increase in the meter reading was observed. This load was recorded as the failure load. The compressive strength was evaluated as

$$
\begin{gathered}
C_{S}=\frac{\text { Failure load }(N)}{\text { Area of blocks }\left(\mathrm{mm}^{2}\right)} \\
C_{S}=\text { compressive strength }
\end{gathered}
$$

\section{2) Abrasive Strength Test}

This test was conducted in accordance with Cal Dive International Inc. (CDI) and Terre (1998). This was first done by placing the block on a horizontal surface for brushing; the wire brush used was laid on the block so that its mass was vertically applied to the block. The surface of the block was brushed using the wire brush to which a $3 \mathrm{~kg}$ mass was attached at the middle. No external force was applied to the brush by the operator. Brushing took place along the whole length of the block. After brushing, all loose matter was removed from the lateritic block and the block reweighed.

$$
\mathrm{Ca}\left(\mathrm{cm}^{2} / \mathrm{g}\right)=\frac{s}{M_{1-} M_{2}}
$$

The mass of the block before brushing $=M_{1}$

Mass of the block after brushing $=M_{2}$

The mass of detached matter $=M_{1-} M_{2}$

The brushed surface area $S=\mathrm{L} \times \mathrm{W}\left(\mathrm{mm}^{2}\right)$

Where $\mathrm{L}=$ Length of brushed face of the block

$\mathrm{W}=$ width of the brush $(25+2) \mathrm{mm}$

\section{RESULTS AND DISCUSSION}

\section{A. Compressive strength of the hardened lateritic block}

Table 1 presents the compressive strength with different percentages of replacement of cement with Periwinkle Shell Ash. Figures 1, 2 and 3 are regression plots of compressive strength against percentage replacement of cement with periwinkle shell ash at 7 th, 14th and 28th days. Generally, the regression plots of compressive strength against percentage replacement of cement with PSA showed negative linear relationship in compressive strength with increase in PSA at the 7th, 14th and 28th days. This is in agreement with Abdulahi (2001) who opined that increase in wood ash content beyond $20 \%$ resulted in a reduction in the compressive strength. This he said was because beyond $20 \%$ there was an excess amount of the ash required to combine with the calcium hydroxide from the hydrating cement.

From the regression plots it was observed that the compressive strength of the blocks with $0 \%, 10 \%, 20 \%$ and $30 \%$ replacement of cement with PSA at the 7 th day were $1.04 \mathrm{~N} / \mathrm{mm}^{2}, \quad 1.00 \mathrm{~N} / \mathrm{mm}^{2}, 0.95 \mathrm{~N} / \mathrm{mm}^{2}$ and $0.74 \mathrm{~N} / \mathrm{mm}^{2}$ respectively; at 14 th days $2.98 \mathrm{~N} / \mathrm{mm} 2,2.81 \mathrm{~N} / \mathrm{mm}^{2}, 2.02$ $\mathrm{N} / \mathrm{mm}^{2}$ and $1.84 \mathrm{~N} / \mathrm{mm}^{2}$ respectively; at 28th day 4.52 
The Effect of Periwinkle Shell Ash (PSA) Blended With Cement on the Compressive and Abrasive Properties of Lateritic Block

$\mathrm{N} / \mathrm{mm}^{2}, 4.02 \mathrm{~N} / \mathrm{mm}^{2}, \quad 3.49 \mathrm{~N} / \mathrm{mm}^{2}$ and $2.56 \mathrm{~N} / \mathrm{mm}^{2}$ respectively. This result shows that the maximum compressive strength at the 28th day up to $30 \%$ replacement of cement witl1 PSA were suitable for non-load bearing walls

Table 1: Variation of density and Compressive Strength of Lateritic Block with curing age

\begin{tabular}{ccccccc}
\hline \multirow{2}{*}{$\begin{array}{c}\text { \% Rep. of } \\
\text { Cement with }\end{array}$} & \multicolumn{2}{c}{ 7th Day } & \multicolumn{2}{c}{ 14th Day } & \multicolumn{2}{c}{ 28th Day } \\
\cline { 2 - 7 } PSA (\%) & Density & Compressive & Density & Compressive & Density & Compressive \\
& $\left(\mathrm{Kg} / \mathrm{m}^{3}\right)$ & $\begin{array}{c}\text { Strength } \\
\left(\mathrm{N} / \mathrm{mm}^{2}\right)\end{array}$ & & $\begin{array}{c}\left.\mathrm{Kg} / \mathrm{m}^{3}\right) \\
\left(\mathrm{N} / \mathrm{mm}^{2}\right)\end{array}$ & & $\begin{array}{c}\text { Strength } \\
\left(\mathrm{N} / \mathrm{mm}^{2}\right)\end{array}$ \\
\hline 0 & 1857.1 & 1.04 & 1761.9 & 2.98 & 1695.2 & 4.52 \\
10 & 1852.4 & 1.00 & 1809.5 & 2.81 & 1690.5 & 4.02 \\
20 & 1881.0 & 0.95 & 1881.0 & 2.02 & 1700.0 & 3.44 \\
30 & 1866.7 & 0.74 & 1871.4 & 1.84 & 175.3 & 2.56 \\
40 & 1866.7 & 0.51 & 1766.7 & 1.02 & 1747.6 & 1.31 \\
50 & 1890.5 & 0.44 & 1776.2 & 0.84 & 1738.1 & 1.01 \\
\hline
\end{tabular}

while at $10 \%$ and $20 \%$ replacement the compressive strength values were suitable for load bearing walls. This aggress with the recommendations of BS 3921 (1974) with a minimum value of $1.4 \mathrm{~N} / \mathrm{mm}^{2}$ for non-load bearing walls and $2.754 / \mathrm{mm}^{2}$ for load bearing walls.

However, beyond $30 \%$ replacement of cement with PSA, the compressive strength values obtained at the 28th day were lower than the minimum value recommended for non-load bearing walls.

\section{B. REGRESSION MODELS}

1) Regression Model for Compressive Strength $0-50 \%$ Replacement of Cement with PSA at 7th Day

The correlation coefficient $\mathrm{R}^{2}$ of 0.934 shows a strong linear relationship between compressive strength of the lateritic block and the percentage replacement of cement with PSA. The value of correlation coefficient $R^{2}$ of 0.934 implies that $93.4 \%$ of the variation in the compressive strength may be accounted for by the linear relationship. From the graph (fig 1)

$$
\begin{aligned}
& \mathrm{Y}=-0.0134 \mathrm{x}+1.1143 \\
& \mathrm{R}^{2}=0.934
\end{aligned}
$$

Where $\mathrm{Y}=$ Compressive strength and

$\mathrm{X}=$ percentage replacement of cement with PSA.

2) 6.2.3 Regression Model for Compressive Strength 0 $50 \%$ Replacement of Cement with PSA at 14th Day

The correlation coefficient $\mathrm{R}^{2}$ of 0.9597 shows a high linear relationship between compressive strength and percentage replacement of cement with PSA. The value of correlation coefficient 0.9597 implies that $95.97 \%$ of the compressive strength may be accounted for by the linear relationship. From the graph (fig. 2)

$$
\begin{aligned}
& \mathrm{Y}=-0.0456 \mathrm{x}+3.041 \\
& \mathrm{R}^{2}=0.9597
\end{aligned}
$$

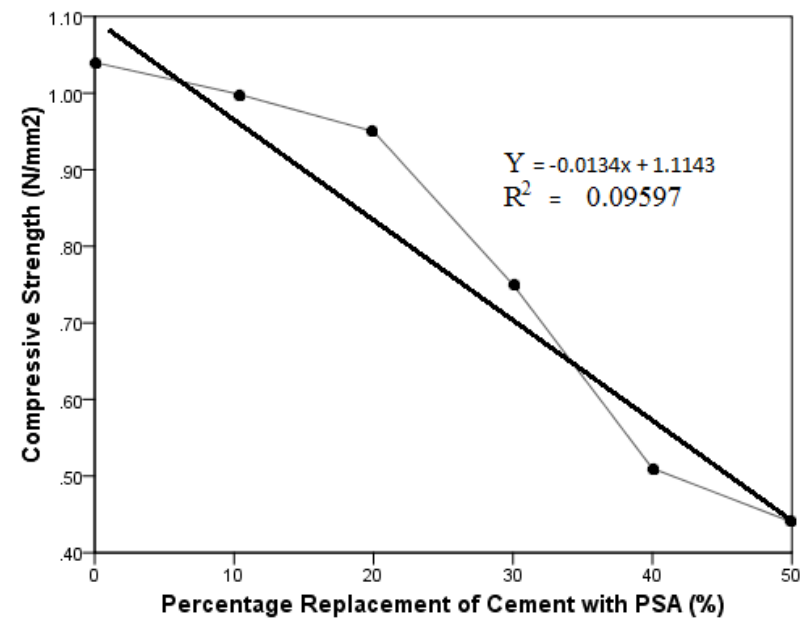

Figure 1: Regression Plot of Compressive Strength against \% Replacement of Cement with PSA at the 7th Day

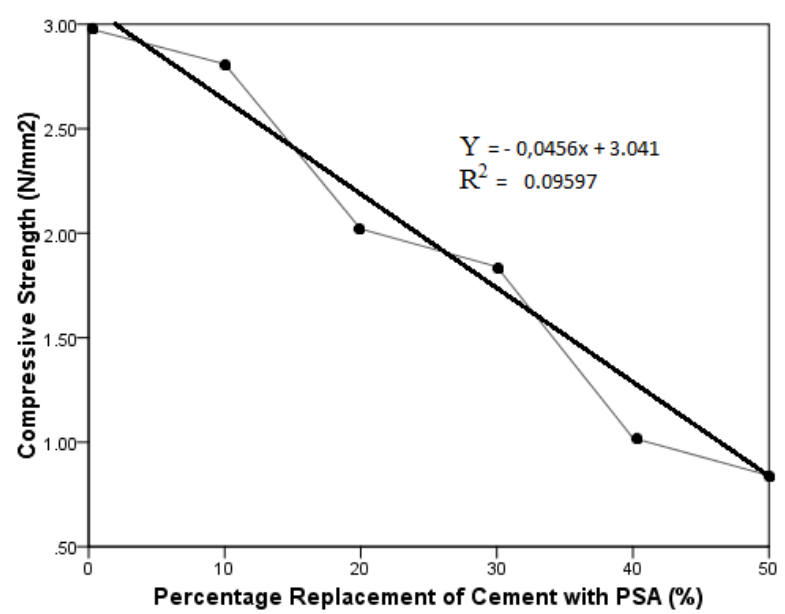

Figure 2: Regression Plot of Compressive Strength against \% Replacement of Cement with PSA at the $7 t$ 
Table 2: Abrasion Test of Lateritic Block

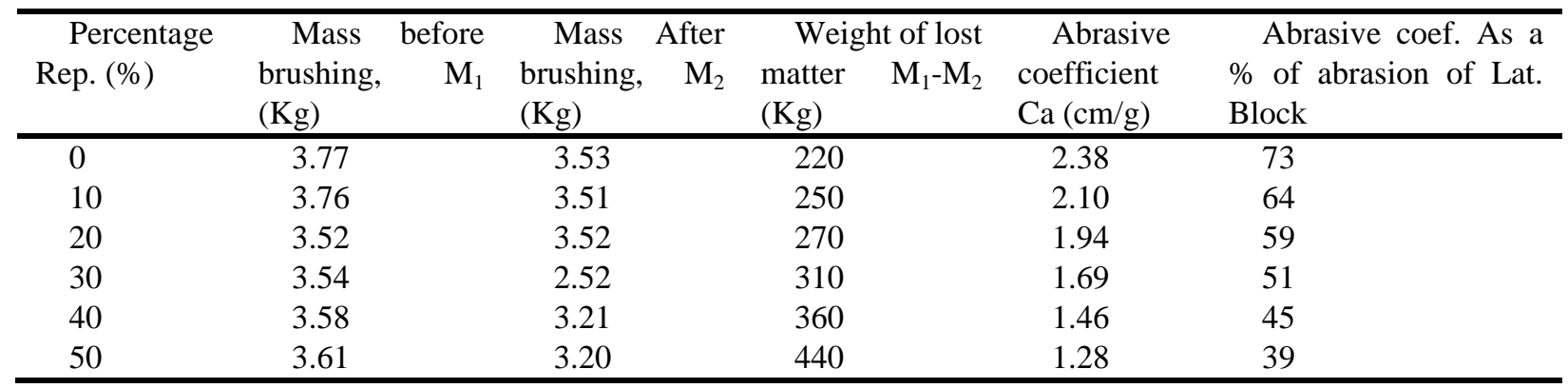

3) Regression Model for Compressive Strength 0 - 50\% Replacement of Cement with PSA at 28th Day

The correlation coefficient R2 of 0.9714 shows a high linear relationship between compressive strength and percentage replacement of cement with PSA. The value of correlation coefficient of 0.9714 implies that $97.14 \%$ of the compressive strength may be accounted for by the linear relationship. From the graph (fig. 3)

$$
\mathrm{Y}=-0.0757 \mathrm{x}+4.7086
$$$$
R^{2}=0.9714
$$

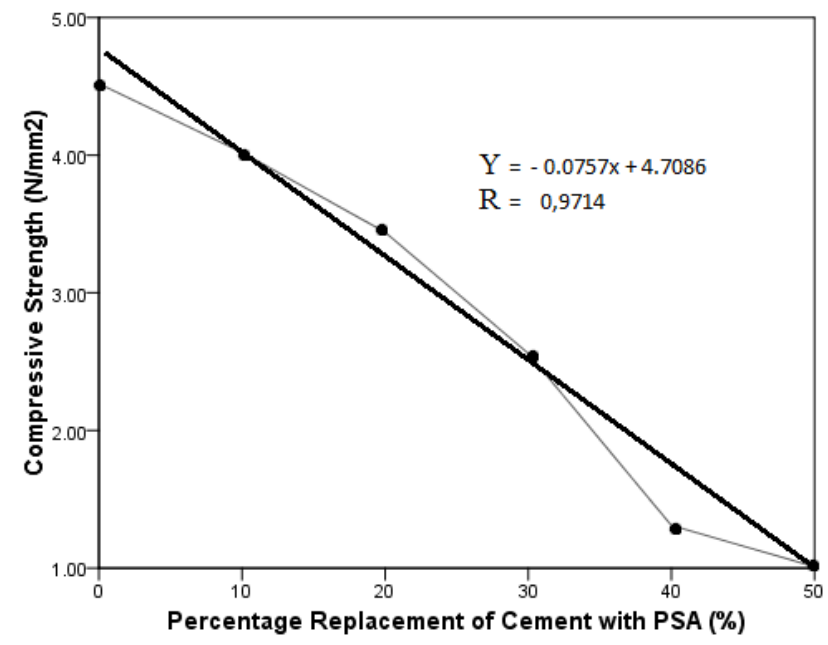

Figure 3: Regression Plot of Compressive Strength against \% Replacement of Cement with PSA at the 28th Day

\section{ABRASSIVE STRENGTH}

The abrasive strength of the lateritic block was compared with the abrasive strength of a normal cement sandcrete block of mix ratio 1:6. The abrasive coefficient of the lateritic block was calculated as a percentage of the sandcrete block.

At zero per cent replacement, the percentage abrasive coefficient was 73 , reduces to 64 at $10 \%, 59$ at $20 \%$ and 51 at $30 \%$ replacement of cement with PSA (Table 2). Beyond $30 \%$ that is from $40 \%$ the percentage abrasive coefficient was below 50\% showing poor abrasive resistance. Eko et al (2006) opined that stabilization of compressed Earth Block using cement increases the abrasive strength of the block. He went further to add that the abrasive strength of earth block was generally low.

From the regression plot (Fig. 4), the correlation coefficient $R^{2}$ of 0.9951 shows that there is linear relationship between water absorption and percentage replacement of cement with PSA. The corre1atiion coefficient of 0.9951 per cent of abrasive strength can be accounted for by the linear relationship. From the graph

$$
\begin{aligned}
\mathrm{Y} & =-0.06714 \mathrm{x}+71.952 \\
\mathrm{R}^{2} & =0.9951
\end{aligned}
$$

\section{SUMMARY OF FINDINGS}

The result of the compressive strength of the hardened blocks revealed that there was high relationship between the compressive strength of the block and the percentage

Table 3: Abrasion Test of 1:6 Sandcrete Block

\begin{tabular}{lccc}
\hline Mass before & Mass After & Weight of & Abrasive \\
brushing, $\mathrm{M}_{1}$ & brushing, & lost matter & coefficient \\
$(\mathrm{Kg})$ & $\mathrm{M}_{2}(\mathrm{Kg})$ & $\mathrm{M}_{1}-\mathrm{M}_{2}(\mathrm{Kg})$ & $\mathrm{Ca}(\mathrm{cm} / \mathrm{g})$ \\
\hline 3.56 & 3.40 & 0.16 & 3.28 \\
\hline
\end{tabular}

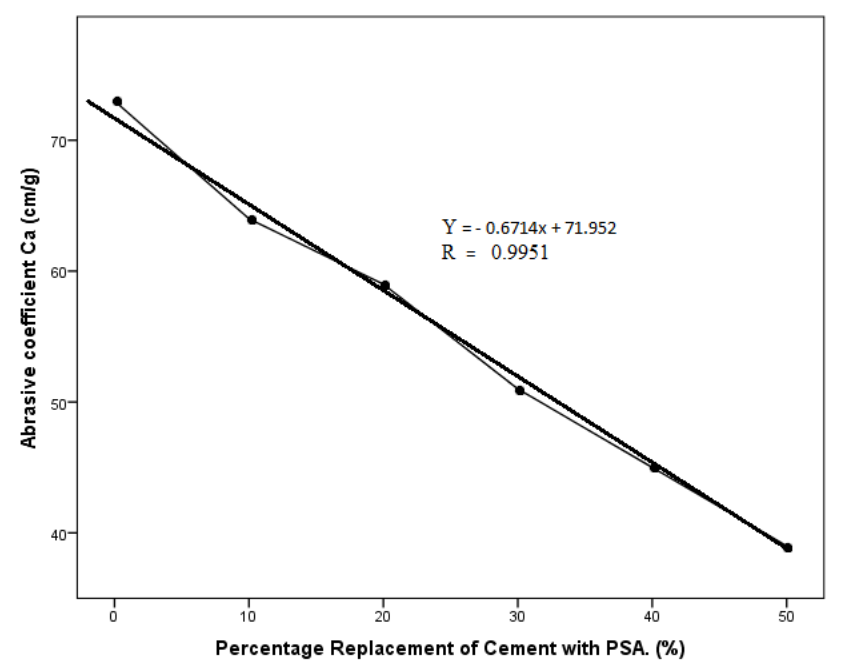

Figure 4: Regression plot of Abrasive Strength at 28th Day replacement of cement with PSA. An increase in percentage replacement brings about a reduction in strength. It was also seen that though there was this decrease, the compressive strength values obtained between $10 \%$ to $30 \%$ 
replacement at the 28th day was high with values of 4.02 $\mathrm{N} / \mathrm{mm}^{2}, 3.49 \mathrm{~N} / \mathrm{mm}$ and $2.56 \mathrm{~N} / \mathrm{mm}^{2}$ for $10 \%, 20 \%$ and $30 \%$ replacement of cement with PSA respectively. This indicates that $10 \%$ and $20 \%$ replacement can be used to produce blocks for load bearing walls while $30 \%$ replacement can be used for non-load bearing walls. A gradual increase in strength was also observed as the curing age increases. For instance at $10 \%$ replacement the compressive strength at the 7 th, 14th and 2 Sth days were $1.04 \mathrm{~N} / \mathrm{mm}^{2}, 2.81 \mathrm{~N} / \mathrm{mm}^{2}$ and $4.02 \mathrm{~N} / \mathrm{mm}$. The result of the percentage abrasive coefficient shows that up to $30 \%$ the abrasive coefficients were appreciable with values of $64 \%, 59 \%$ and $51 \%$ for $10 \%, 20 \%$ and $30 \%$ respectively. Above $30 \%$ the percentage abrasive coefficients were low. This is in line with Rigassi (1995) who opined that the abrasive strength increase with the increase in amount of cement.

\section{CONCLUSION}

Within the limits of the study and findings, the following deductions where made.

a. That up to $30 \%$ replacement of cement with periwinkle shell ash, the compressive strength of the block at the 28th day was suitable for non-load bearing walls while $10 \%$ and $20 \%$ replacement gave high values suitable for load bearing walls.

b. That the percentage abrasive coefficient of the block was appreciable up to $30 \%$ replacement, with a value of $51 \%$. Above $30 \%$ replacement, the values were too low (below 50\%).

\section{RECOMMENDATION}

It is pertinent to make the following recommendation as a follow up to this research:

a. The Lateritic block had compressive strength $\left(4.02 \mathrm{~N} / \mathrm{mm}^{2}\right.$, $3.49 \mathrm{~N} / \mathrm{mm}^{2}$ and $2.56 \mathrm{~N} / \mathrm{mm}$ ) suitable for wall construction.

b. The abrasive strength of the lateritic blocks compared with 1:6 sandcrete blocks indicate that the abrasion resistance of the blocks was high; hence, the lateritic block is recommended for use in wall construction.

\section{REFERENCES}

[1] Z. Mustapha, "Center for Human Settlements and Urban Development" Federal University of Technology. Journal of Science and Industrial Studies (2004), Vol. 2.

[2] D. Arilesere, "Materials Development for low cost building". Handbook for Building construction (2005). Ediwen Press Nigeria, pp $66-70$

[3] I. Udegbe, "Labour Force Capital on Plastering Activity in Edo State". The professional Builder, Journal of the Nigerian Institute of Building (2005)

[4] M. Lilly and J. Wai, "The Professional Builder" Journal of the Nigerian Institute of Building (2001), pp. 48.

[5] A. Okpoko and J. Ali, "Need for Quality in the Production of Cement Stabilized Soil Blocks for Walling in Nigeria". The professional Building Journal of the Nigerian Institute of Building (2005), pp. 64 72.

[6] P. Meukam, A. Noumowe and T. Kofane, "Thermophysical Properties of Lateritic Soil Bricks: Influence of water content”. United Nations Educational Scientific and Cultural Organization and International Atomic Energy Agency (2002). Available at: http://www.ictp.trieste.it/ pub off

[7] D. Adesanya, The characteristics of laterite bricks and blocks stabilized with corncob fillers. The professional Builder, Journal of the Nigerian Institute of Building (2000). pp 47- 55.
[8] E. Adam and A. Agib, "Compressive stabilized earth block manufactured in Sudan”. United Nations Educational Scientific and Cultural Organization (2001).

[9] R. Craig, "Basic Characteristics of Soil". In Craig's Soil Mechanics, (2004). London Spon Press, pp. 1 -29

[10] H. Afrin, "A Review on Different Types Soil Stabilization Techniques". International Journal of Transportation Engineering and Technology (2017), Vol. 3, No. 2. pp. 19-24. Retrieved from: http://www.sciencepublishinggroup.comj/ijtetdoi: 10.11648/j.ij tet. 20170302.12.

[11] H. Guiland and T. Joffroy "Manual of Design and Construction, Compressed Earth Blocks" (1999), Vol.2. A Publication of the Deutsches Zentrum, Deutsche Gesellschaft ISBN 3-528-02080-6

[12] British Standard Institution BS 3921 (1974), Clay Bricks and Blocks London.

[13] Y. Balami, and Y. Izam, "Soil Bitumen as a Walking material". Journal of Environmental Science (1998), 2(1): pp. 29 - 34.

[14] O. Okoli, "Unconfined Compressive Strength and durabilityof Lime - Clay Soil for Bulding Construction". Nigerian Journal of Construction Technology and Management (1998), 1(1). pp 1 - 5.

[15] B. Waziri, Z. Lawan and M. Mustapha, Properties of Compressed Stabilized Earth Blocks (CSEB) For Low Cost Housing Construction: A Preliminary Investigation. International Journal of Sustainable Construction Engineering \& Technology (2013), (ISSN: 2180-3242),4(2). Retrievedfrom: http://penerbit.uthm.edu.my/ojs/ index.php/IJSCET/article/ viewFile/659/478.

[16] R. Eko, M. Mpele, D. Dtawagap, S. Minsili and A. Wouatong, "Some hydraulic, mechanical, and physical characteristics of three types of compressed earth blocks". Engineering International, the CIGR Journal ( 2006), . Vol. VIII.

[17] H. Houben and H. Guillanud, "Earth Construction a Comprehensive Guide, CRATeere - EAG” (1994). Intermediary Technology Publication, London.

[18] V. Riggasi, "Building with Soil-Cement Bricks in Building Research and Practice”. Internal Council for Building Research, (1979), 2(26), pp $80-90$.

[19] American Standard for Testing and Materials ASTM: C61S - 78 (1978)

[20] CDI and Terre Compressed Earth Blocks Standards. (1998), ISBN 2-906901-18-0.

[21] M. Abdullahi, "Characteristics of Wood Ash/OPC Concrete". Civil Engineering Department, Federal University of Technology, Mina, Niger State (2001).

Antia, Mfon Ekanem Department of Building, University of Uyo, Nigeria. BSc. Building (University of Uyo), MSc. Building Maintenance (Obafemi Awolowo University), PhD (in-view) Building Maintenance (Obafemi Awolowo University). Member Nigerian Institute of Building. Specialization: Building Maintenance.

Ajiero, Ikenna Reginald Department of Building, University of Uyo, Nigeria. BSc. Building (University of Uyo), MSc. Building Services Engineering (Glasgow Caledonian University), PhD Construction (Herriot Watt University). Member Nigerian Institute of Building. Specialization: Building Services.

Ulaeto, Nsikak William Department of Building, University of Uyo, Nigeria. BSc. Building (University of Uyo), MSc. Structural Engineering (University of Surrey), $\mathrm{PhD}$ Civil and Environmental Engineering (University of Surrey). Member Nigerian Institute of Building, Fellow Higher Education Academic (United Kingdom). Specialization: Materials and Building Structural Systems. 